DOI: 10.35784/IAPGOS.36

\title{
CONCEPT OF A SELF-LEARNING WORKPLACE CELL FOR WORKER ASSISTANCE WHILE COLLABORATION WITH A ROBOT WITHIN THE SELF-ADAPTING-PRODUCTION-PLANNING-SYSTEM
}

\author{
Johanna Ender ${ }^{1,2}$, Jan Cetric Wagner ${ }^{2}$, Georg Kunert ${ }^{2}$, Fang Bin Guo ${ }^{1}$, Roland Larek ${ }^{2}$, Thorsten Pawletta ${ }^{2}$ \\ ${ }^{1}$ Liverpool John Moores University, Faculty of Engineering and Technology, Liverpool, United Kingdom, \\ ${ }^{2}$ Hochschule Wismar, University of Applied Sciences: Technology, Business and Design, Faculty of Engineering, Wismar, Germany
}

Abstract. For some time, the focus of past research on industrial workplace designs has been the optimization of processes from the technological point of view. Since human workers have to work within this environment the design process must regard Human Factor needs. The operators are under additional stress due to the range of high dynamic processes and due to the integration of robots and autonomous operating machines. There have been few studies on how Human Factors influence the design of workplaces for Human-Robot Collaboration (HRC). Furthermore, a comprehensive, systematic and human-centred design solution for industrial workplaces particularly considering Human Factor needs within HRC is widely uncertain and a specific application with reference to production workplaces is missing.

The research findings described in this paper aim the optimization of workplaces for manual production and maintenance processes with respect to the workers within HRC. In order to increase the acceptance of integration of human-robot teams, the concept of the Assisting-Industrial-WorkplaceSystem (AIWS) was developed. As a flexible hybrid cell for HRC integrated into a Self-Adapting-Production-Planning-System (SAPPS) assists the worker while interaction.

Keywords: human-robot collaboration, human factors, post-optimised reinforcement learning algorithm, self-adapting-production-planning-system

\section{KONCEPCJA SAMOUCZĄCEGO SIE STANOWISKA PRACY \\ DLA WSPIERANIA PRACOWNIKA PRZY WSPÓLPRACY Z ROBOTEM W UKLADZIE SAMOADAPTACJA-PRODUKCJA-PLANOWANIE}

Streszczenie. Wcześniejsze badania nad projektami przemysłowych miejsc pracy koncentrowaty się od pewnego czasu na optymalizacji procesów $z$ technologicznego punktu widzenia. Ze względu na konieczność pracy ludzi $w$ takim środowisku, proces projektowania musi uwzględniać potrzeby czynnika ludzkiego. Operatorzy znajduja się pod dodatkowym obciązeniem ze względu na zakres procesów o wysokiej dynamice, integrację robotów $i$ autonomicznych maszyn roboczych. Stosunkowo niewiele badań dotyczy wpływu czynników ludzkich na projektowanie miejsc pracy na potrzeby układów Human-Robot Collaboration (HRC). Co więcej, wszechstronne, systematyczne i ukierunkowane na człowieka rozwiazanie projektowe dla przemysłowych zakładów pracy, szczególnie uwzględniające potrzeby czynnika ludzkiego w HRC, jest szeroko niepewne $i$ brak jest konkretnego zastosowania w odniesieniu do miejsc pracy w produkcji.

Opisane $w$ artykule wyniki badań maja na celu optymalizację miejsc pracy dla ręcznych procesów produkcji $i$ utrzymania ruchu, $w$ odniesieniu do pracowników w HRC. W celu zwiększenia akceptacji integracji zespolów ludzko-robotycznych opracowano koncepcję systemu wspomagania miejsca pracy (ang. Assisting-Industrial-Workplace-System, AIWS). Jako elastyczna komórka hybrydowa dla HRC zintegrowana z Samo-Adaptacyjnym Systemem Planowania Produkcji (ang. Self-Adapting-Production-Planning-System, SAPPS) pomaga pracownikowi podczas interakcji.

Słowa kluczowe: współpraca człowiek-robot, czynniki ludzkie, zoptymalizowany poprawiony algorytm uczenia się, układ samoadaptacja-produkcja-planowanie

\section{Introduction}

A major reason for the general change in the way of working particularly in industry, is the integration of machines, computers and smart devices $[23,31]$. The term digitized industry will be used within this paper to refer to the merge of Industry 4.0 (I4.0) and the Industrial Internet of Things (IIoT). In this context, CyberPhysical Systems (CPS) evolved as a significant element [23]. These systems contain autonomous operating machines and storage systems and a continuous exchange of information is typical [31]. Tasks within Human-Machine Interaction (HMI), in particular, the interaction with robots will be increasingly integrated into the work process in the future $[8,17]$.

Currently, there is still a strict separation between workers and robots through fences and safety systems, but further advances of coexistence, cooperation and collaboration of humans and robots have been classified [21]. Within cooperation, humans and robots work towards higher common goals; however, there is still a clear division of their tasks. In Human-Robot Collaboration (HRC) partial goals are also pursued together. To ensure this, the safe and comfortable collaboration of humans and robots is sought [24, 35].

In order to create a human-centred design solution to resolve issues identified within the digitized industry, Human Factors knowledge has been adopted to develop the concept of an Assisting Workplace Cell for HRC to minimise cognitive load, increase the acceptance of the worker and increase the productivity. To develop the concept of an Assisting-IndustrialWorkplace-System (AIWS) the three level of ergonomics/human factors [36] have been investigated:

- Physical level - anthropometrics of the human body and physical interaction.

- Cognitive level - psychological perception.

- Organisational level - design of socio-technical systems.
The concept removes traditional input and output devices such as monitors, keyboard and PC-mouse and employs the surface of the table as an interface that is connected with a Self-AdaptingProduction-Planning-System (SAPPS). In addition, to reduce strain, the integration of a post-optimization reinforcement learning algorithm within the workplace system will enable a situational adaptation of the spatial movements of the robot to the behaviour of the worker. The individual adaption of the AIWS to Human Factor needs will improve the well-being of the worker and increases the integration of HRC.

\section{State of the research}

Bullinger [4], Bullinger-Hoffmann and Mühlsted [5] show that the design of workplaces for HMI needs not only to consider the ergonomic requirements, but also psychological aspects to assist the operator.

Psychological influences have an effect on workers' health and wellbeing whilst working in an industrial environment. Goschke [9] cites the Yerkes-Dodson-law [28], according to which human performance in information processing depends on the complexity of the task and mental activation. A high level of nervous stimulation significantly lowers performance in solving complex tasks. This corresponds to Braseth's [3] suggestion that one of the main issues for designing visual interfaces is to avoid information overloading. The higher dynamics of processes within industry require a permanent interpretation of signals and adequate reactions of the operator. Endsley and Jones [7] outlined how the human brain becomes a bottleneck when the design of work equipment does not provide support for rapid information processing. An adequate design will help to overcome the bottleneck by promoting the rapid reception of information and supporting the interpretation process. Similarly, Bauernhansl [2] 
draws attention to the flood of data resulting from global networking and ever-improving device technology and concludes that the support of the worker in the production plant is getting increasingly important. In the same way, the BMBF [34], refers to the importance of assistance systems within changing working environments.

Today, the character of industry is changing, and the role of product design has been altered. Sanders and Staplers [22] concluded that industry had been primarily manufacturing-driven and then shifted to technology-driven. Currently, the industry is motivated by the stagnation of the technology push and the user experience appears to be the focus of investigations. In the enquiry of the role of design within I4.0, IXDS Human Industries Venture [37] reports that design improves manufacturing processes when involving all stakeholders early. Accordingly, the user-centred design landscape is developing into an environment of co-creation, where workers are involved in the design process from the early stages [22]. Norman [20] believes that anyone can design, due to their own creative potential. In addition, Steelcase Inc. [39] requires supporting creativity at work so as to create value for business and society. Supporting this potential for creativity and new high-flexible forms of diverse cooperation teams will be the task of workplace design in the future. Given the discussions above, IXDS Human Industries Venture [37] declares that design will facilitate the development of systems to empower skilled operators and non-experts at the same time, and resulting in processes usable for a large number of worker.

Product design is not only concerned with the aesthetic design of the exterior form but also with the proper interfaces for users interacting with the system/environment. With the increasing automatization of the industry, Lee [16] suggests that consideration of Human Factors in design tends to be significant. Contemporary design takes all aspects of ergonomics into account, in particular, the psychological impact on employees.

A growing body of literature examines the features and requirements of the fast-changing production processes within the digitized industry; their findings [27] highlight the new quality of linking production systems as one of the main advantages of the digitized industry. On the other hand, the digitized industry is characterized by dynamic processes with increasing complexity. Approvingly, Acatech [31] comments that an equally important feature of digitised industry results from smart assistance systems which release workers from having to perform routine tasks, instead of focusing on creative and value-added activities. Given a panorama view of research on assistant scenarios, it provides different approaches that aim to support the worker within the industrial environment. In one example: researchers have developed the integration of guidance lights and projections within the workplace environment to instruct the worker [1, 32]. Other approaches focus on the integration of screens or wearables to support the worker in manual production processes [10] or on the interaction with CPS in general [29]. The integration of robots has aimed to reduce the strain of the workload [18, 19]. Sensitive robots facilitate interactions between the CPS and workers through physical contact instead of screens [30]. Furthermore, experts draw attention to machines which are able to increasingly adapt to individual abilities and needs of the worker [30, 33]. Self-learning algorithms process a large amount of data and accommodate the system to different environments [14].

Vogel-Heuser, Bauernhansl and ten Hompel [25] employed the term versatility to satisfy the requirements of unpredictable commerce changes and to highlight the value of production systems, which can be transformed according to the order situation with minimal effort. These versatile systems are also able to overcome the limitations of traditional production and maintenance systems in dealing with increasing customization of products and small batch sizes. Individual customer requirements can be taken into account and even the industrialized manufacture of individual pieces and production for small batch sizes is profitable [31].

Given these discussions, ten Hompel and Henke [12] comment that a system needs to accommodate its circumstances at all times. The industrial plant of the future must be able to move its regional location effortlessly. Hackl, Wagner, Attmer and Baumann [11] emphasise that in response to technological and economic volatility, the expectations of employees in the 'New Work' have changed.

\section{The concept of an Assisting Workplace Cell}

The following section discusses how an appropriate product design helps to improve the performance and usability of an HRCworkplace system.

\subsection{The Assisting Workplace as a hybrid cell: contribution to the flexible manufacturing}

The concept of flexible manufacturing systems enables highly adaptable production $[6,38]$. The principal value results from the flexibility of the configurable production cells, where robots are able to handle and add in parts. Tool magazines next to the robot supply the adaptation of the gripper to the work task. Material, parts and further tools are transferred from the warehouses and tool stores to the specific cell, i.e. using automated guided vehicles. Overall, the production is controlled by a decentralized intelligence that connects all parties and is able to communicate, e.g. over the Internet of Things. The workpieces, machines and the process constantly delivers and exchanges process data [38]. These flexible and scalable systems provide an attractive perspective on future production.

Nevertheless, this concept lacks integration of the workers and the adaptation of workplaces for the HMI / HRC regarding Human Factor needs.

\subsection{AIWS integration within the production system}

The research described in this paper provides a cell for hybrid teams. A cell contains an AIWS for HRC and supports workers interacting with the CPS, e.g. solving of assembly and maintenance tasks (Fig. 1, Fig. 2). The AIWS works as a hybrid cell which is developed based on a real-world scenario from the digitized industry.

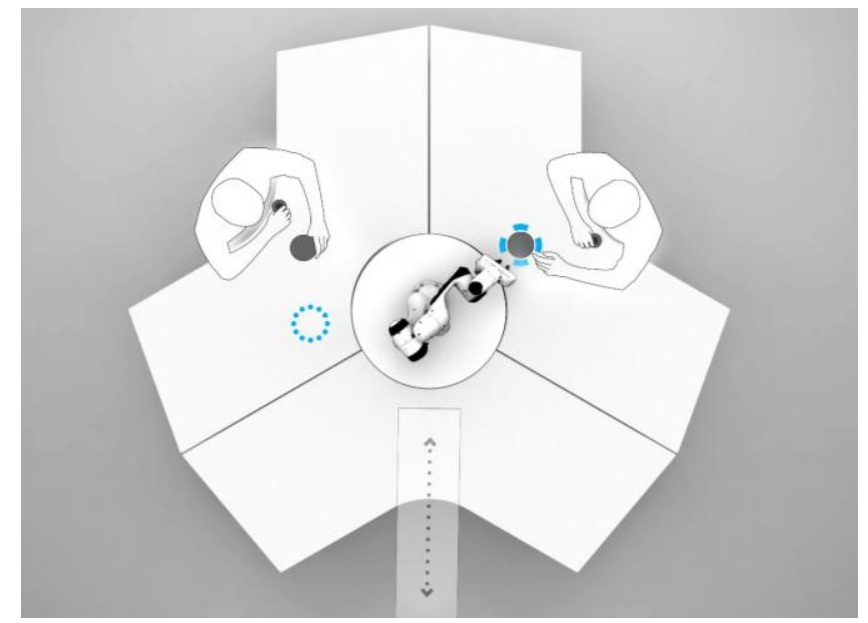

Fig. 1. The concept of the prototype of an assisting workplace for HRC. It includes an integrated Franka Emika robot handling tools and work-pieces which have been delivered by a conveyor belt 


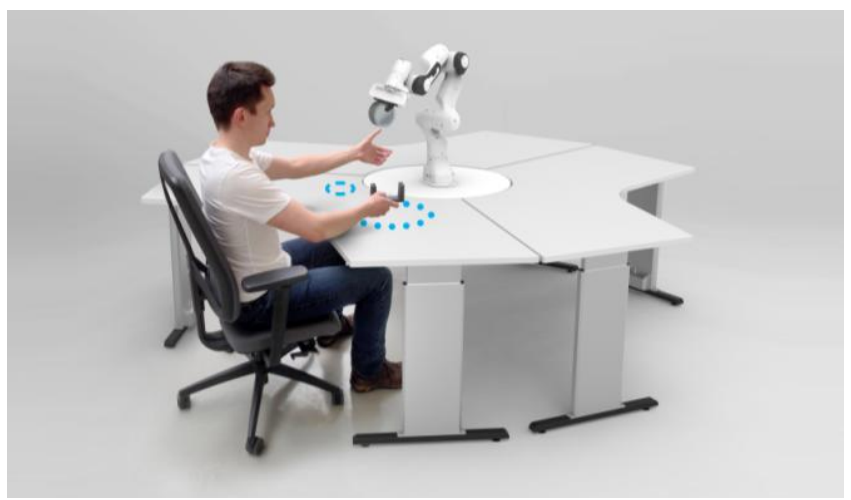

Fig. 2. AIWS-Concept rendering

Elements of automated production systems within a digitized factory include machines, tool stores, warehouses, manual workstations and HRC-workplaces. These are constantly networked together and sharing their current status. The AWIS extends flexible manufacturing systems by including workplaces for hybrid human-robot teams in order to promote manual tasks (Fig. 3, Fig. 4).

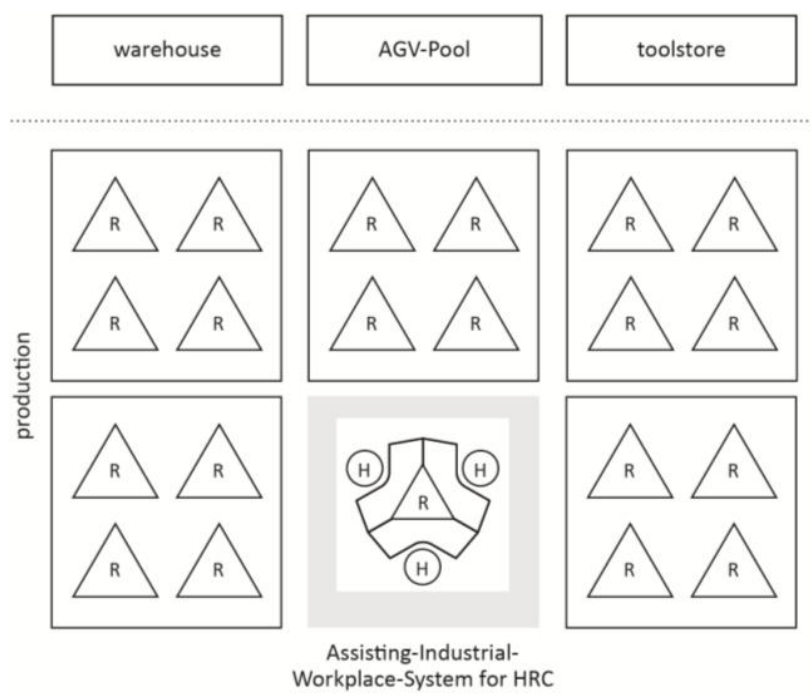

Fig. 3. Integration of the hybrid production cell for HRC as advance of the Matrix Production adapted from [20] (R - Robot; H - Human)
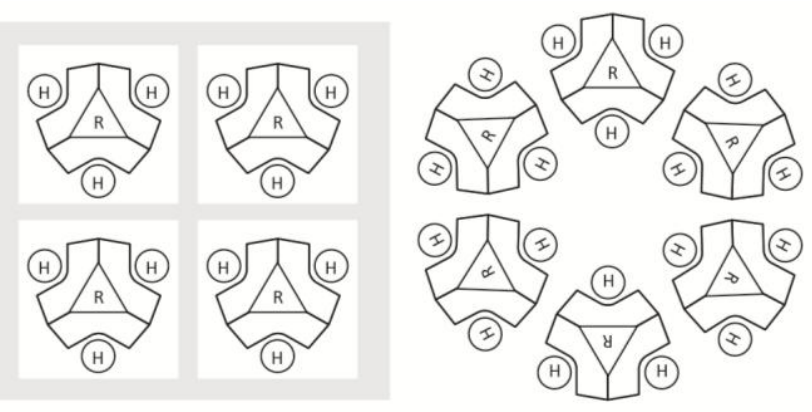

Fig. 4. AIWS - Composition variants of individual cells ( $R$ - Robot; H-Human)

In the background of the assisting workplace, an extended network plan (ENP) controls dynamically the work orders according to the order situation and existing resources [15]. It is a specification of a Self-Adapting-Production-Planning-System (SAPPS) that improves this workflow within the production system. The ENP demonstrates additionally to all steps that are necessary for products assembly, alternatives for several tasks [26]. Fig. 5 visualizes an example of ENP.

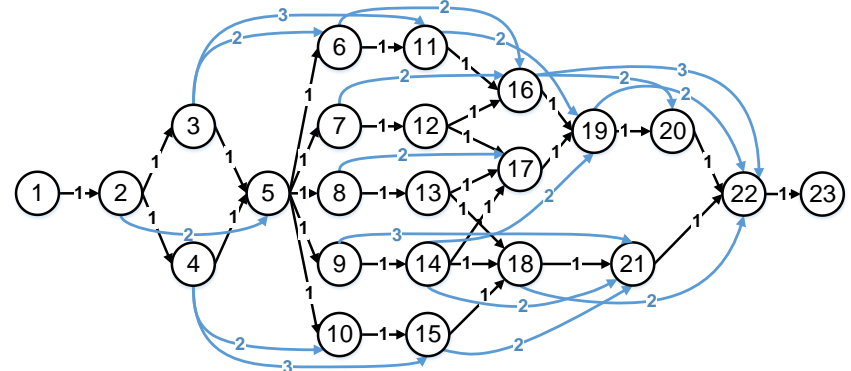

Fig. 5. The extended network plan - an example of an assembly sequence for an industrial production process

The arrows are weighted with a quantifier $\mathrm{x} ; \mathrm{x}=1$ represents the ideal assembly process; all other arrows with $x \geq 2$ represents the alternatives. The ENP algorithm calculates these weights. All needed information like predecessors, successors, preconditions as well as possible alternatives for each job is stored in a database. Whereby, this system is able to respond to constantly changing conditions, e.g. failure of a machine or bottlenecks in the delivery of materials. In situations where alternatives are needed, it provides solutions to the worker which can be done instead of non-available jobs. The ENP algorithm analyses and evaluates the different alternatives based on several parameters such as preconditions, arrow weight and job relevance in the whole assembly process. In the future, the industry will be able to control both incoming and outgoing materials and available tools in tool stores via an automatic and networked storage system include conveyor belts, mobile and autonomous vehicles and robots. The required parts and tools are transferred to the specific homogeneous cells (Machine to Machine) or heterogeneous cells (HMI and HRC). At the workplaces for manual tasks in collaboration with the robot, this robot receives the delivery and handles it to the specific employee. The flexibility of this system is very high-level, including assembly, maintenance, testing, packaging. All work steps can now be performed on the same workbench system of that cell.

In addition, a hybrid form through the integration of machines within a section of the cell is feasible, e.g. two workers and one collaborative robot working with one machine.

\subsection{The user experience concerning the AIWS}

When starting work, an employee selects a free workplace randomly from one of the many islet cells in the production hall. Based on flexible office-organizational concepts such as the Co-Working Spaces, Collaboration Platform or Desk Sharing, the workplaces of a workbench system cell are freely available to every employee.

When the employee logs into the system through an electronic ID, the workbench will adjust the table height to the individual preferred and previously stored level, and the employee's specific settings such as lighting environment, colour preferences etc. In addition, the system recognizes the employee's skill description and offers suitable work tasks for the current order situation. The CPS adjusts itself independently, to support the specific work task, e.g. the required tools and work pieces are conveyed to the cell and then are supplied to the workplace with the help of the collaborative robot. Subsequently, the employee performs the work steps. The surface of the table serves as an interactive user interface (UI) and guides the employee through the assembly and/or maintenance process. The interface is also motivating during the day, it provides a positive visual response to work assignments completed and reminds the worker to observe break times. The robot assists employees in solving a wide variability of work tasks, for instance through the integrated measuring 
equipment, the robot could assist with quality-relevant decisions for the reduction of subjective influences by the employee. The broad variety and adaptivity of the end-effectors of the robot offer the possibility of adapting to the requirements of the networked production lines and its current tasks. For example, determining the surface quality can be implemented by scanning the workpiece with a specific effector.

The concept allows a variety of degrees of freedom for the employees and enables and supports the intuitive interaction with the system:

- Free division of working time.

- Freedom in choosing the place of work.

- Freedom of selection of the scope of work

- Adaptation of the work assignment to specific qualifications.

\subsection{User Interface concept - Work-by-Light}

Part of the AIWS is the development of a communication channel to support the interaction between worker, robot and network. The system will now be introduced by using the term Work-by-Light (WbL).

Derived from the existing Pick-by-Light framework - where operators are directed to particular stock areas via light signals the $\mathrm{WbL}$ system includes a UI that directs work tasks to the worker within the networked plant. The UI utilizes light displays to support operators conducting specific work tasks in collaboration with a robot (Fig. 6). In addition, the light signals give an indication of the future movements of the robot.

Light signals of the AIWS as a communication channel:

- Status display of the robot (active, inactive, error).

- Input and output interface (e.g. work instructions, switching on/ off/ pausing the system).

- Display of the direction of movement of the robot by marking relevant zones on the workbench.

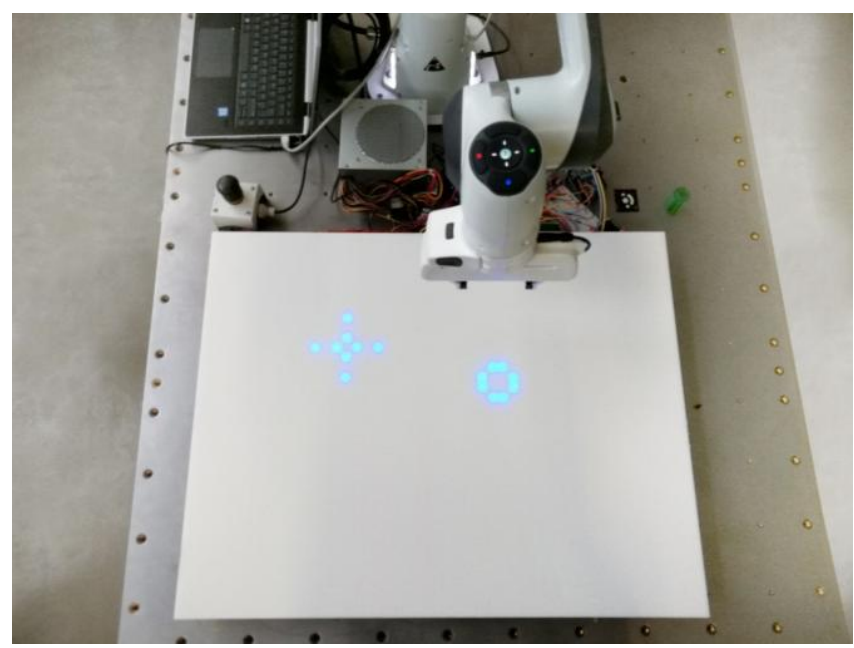

Fig. 6. The prototype of the UI framework which supports the worker during task solving

In order to minimize the cognitive overload of the worker and to create more free space at the workplace, the table surface itself will be the input and output device. The concept of an innovative and simplified display technology based on a LED-matrix connected with the high performance acrylic solid material was successfully developed. The translucent material is illuminated from below with LEDs. These LED-Matrix can be controlled via a microcontroller. It gets an RGB image from the control computer. The microcontroller extracts the individual pixel information from the image and generates the control of the individual LEDs.

Light signals inside the surface of the table are reduced to the minimum of information to support the rapid processing of the instruction through the worker in order to support the intuitive utilization of the interface and consequently reduces strain in HRC.
Since autonomous robot movement rhythms are generally not predictable, there are still barriers in the HRC that cause stress. The development of the light-guidance system will help the employee to forecast the movements of the robot, and reduce the need for these barriers.

\subsection{Set up of the Demonstrator}

The assistance system consists of different interconnected components. Fig. 7 demonstrates individual actuators within the concept layout. Based on this structural concept, the pilot workplace for running future experimental studies on user acceptance was already successfully set up at the laboratory of Hochschule Wismar (Fig. 8).

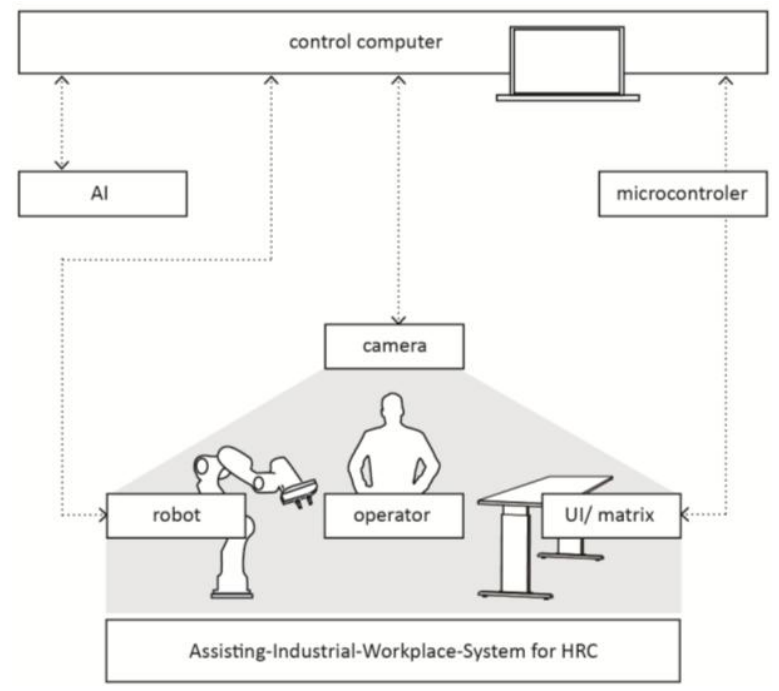

Fig. 7. Structure and communication of the single actuators of the AIWS for HRC

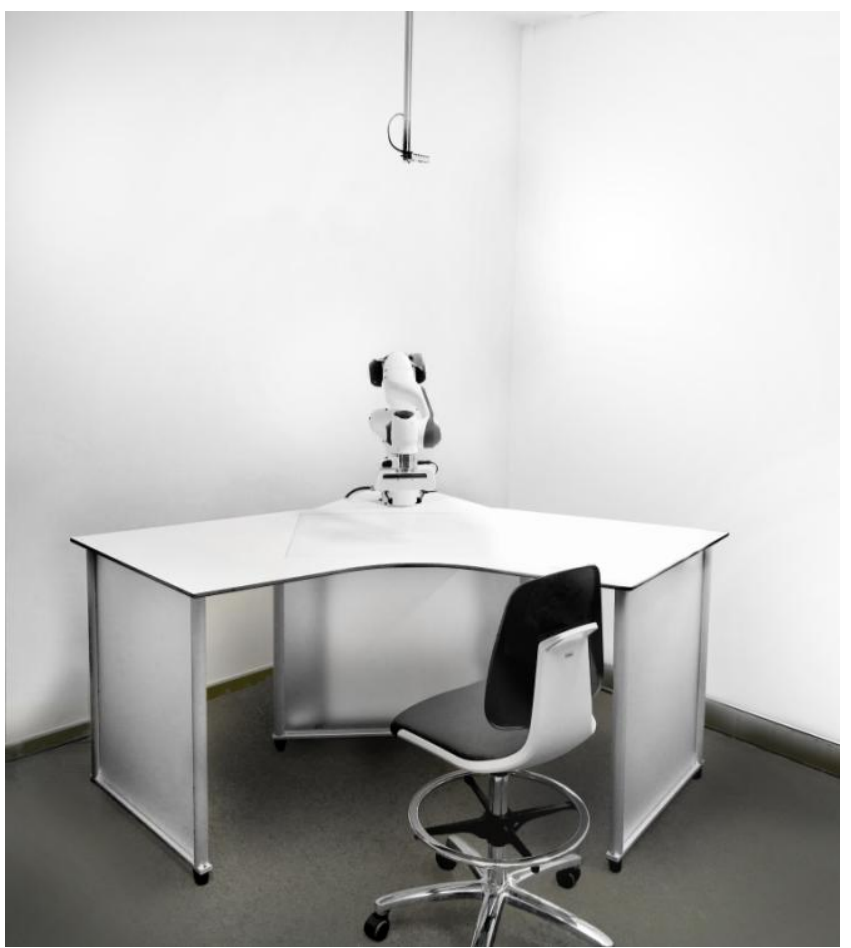

Fig. 8. Set up of the AIWS pilot workplace at the laboratory of Hochschule Wismar A camera-system is attached to the ceiling and tracks the workplace

The operator inputs information through gestures tracked by the common camera-system. The control computer inspects the situation with the camera-system and makes its decision with help of a learned behaviour. If the situation is new to the control computer, it will transmit the situation to an artificial intelligence 
(AI) component on a mainframe. The mainframe processes this data through post-optimizing reinforcement learning [13] and adjusting the behavioural strategy of the system; after that, the control computer receives the new behavioural strategy.

The control computer generates the robot control program from the learned behavioural strategy. The actions that are suggested from the control computer are positions and/or paths of the robot. The safety functions are still in the controller of the robot.

Moreover, in achieving this aim, the machine learning method will be employed to develop a highly flexible and self-learning robot control program. The program will be able to interact with the employee and production workflow independently, through a model-based learning pattern. The program is also expected to respond adequately to unknown circumstances. Thus, it is imperative that alternative sequences will be learned. The learning process consists of two steps: the real-world process will be simulated with a model and learned (i) offline with the postoptimizing reinforcement learning; then machine learning needs to improve (ii) online for the entire operating time.

The following system elements are derived from the concept and will be developed/implemented by the research group Computational Engineering and Automation (CEA) at the Hochschule Wismar, University of Applied Sciences: Technology, Business and Design:

- Autonomously learning robot control program, which is able to find an order of tasks for the assembly to receive a short production time using with the post-optimizing reinforcement learning [13].

- Secure movements, which do not hinder or distract the worker

- A robot control program, which proactively responds to the individual behaviour of the worker.

While learning, the Reinforcement Learning algorithm switches between exploration - acting randomly and finding new states, and exploitation - choosing the best so far known action to reaches as fast as possible the given target. By switching between these two modes, the algorithm learns alternative sequences for solving a problem. While learning offline, the control program always regards the security of the worker within the workplace environment.

After the control program has learned offline, the algorithm has to proactively learn online at the real environment. Even if a path of the robot is blocked by a human or by an obstacle, the algorithm independently chooses an alternative route for the robot to move to the targeted position without disturbing the worker.

However, the movements of the employee will be recorded with a camera-system and evaluated with a standard computer. The analysis of the picture (Fig. 9) marks the position and body dimensions of the worker on the surface of the workbench. Furthermore, images of objects, such as tools and workpieces, can be stored in a database and recognized afterwards within the real environment.

The robot control will use this data. Theoretically, calculating the behavioural strategy of the robot can be completed by any computer, however, it requires a lot of time for calculation. A mainframe computer is advisable for the calculation to process new/unknown states of the manufacturing process, so the control computer reacts adequately when these conditions are encountered again.

Accordingly, it is possible that the robot control program as well as the UI accommodates itself to the behaviour of the employee using the recorded data and calculated by the control computer.

Connected with the UI, the overall system will be able to accommodate the specific/inconstant behaviour and performance variability of each employee. For this purpose, the robot will proactively adapt the constantly changing movement model of the employee. Since it is impossible for the robot control program to simulate human's behaviour and as it is not predictable, a rigid control program will not be able to complete this task.

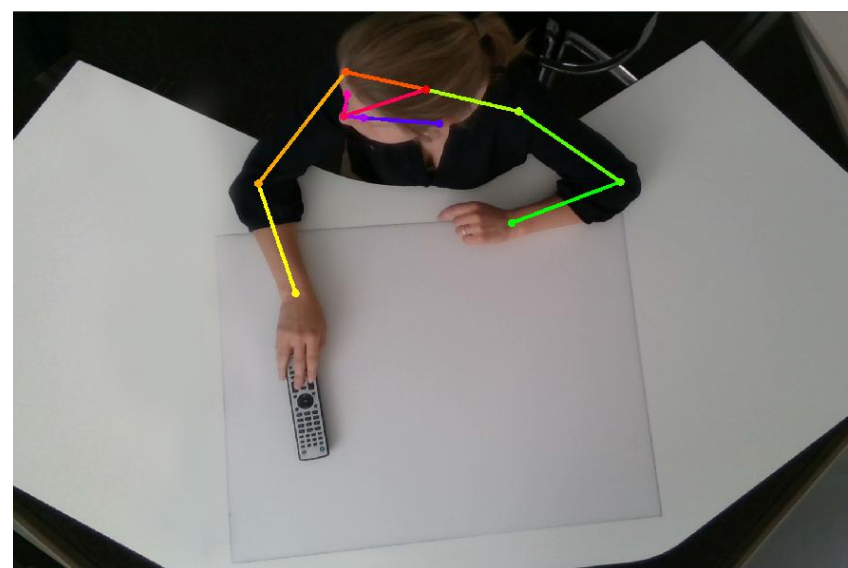

Fig. 9. Camera-Tracking at the demonstrator - The system recognizes the position and dimension of the human skeleton. As a result, the movements of the workers can be detected safely. A recognition and evaluation of gestures would also be possible in the future development - an integration in the pilot system is currently being tested for their relevance for use and implementability

\section{Summary and outlook}

The motivation of the research was to reduce the level of stress, physical and cognitive strain of the operators while working at assembly and maintenance tasks and support the integration of HRC within the digitized factory to increase the productivity. As a contribution to the flexible manufacturing system, the concept of AIWS for HRC has successfully developed as a flexible hybrid cell design.

The concept considers the three dimensions of Human Factors in design:

Physical level: The AIWS with an integrated robot will be able to accommodate behaviour patterns of the employee to satisfy ergonomic and $\mathrm{HRC}$ requirements using machine learning.

Cognitive level: The WbL-concept accelerates the reception of information and assisting the interpretation process to reduce strain during the $\mathrm{HRC}$ process.

Organisational level: The hybrid cell integrated into a SAPPS and combined with the advantages of the ENP enables the industry to transform according to the order situation with minimal effort and allows a variety of freedoms for the employees, e.g. division of working time.

Considerable progress has been made to the iterative development of the concept, the construction, and prototyping of a demonstrator. Further research will be investigating and exemplifying how the AIWS supports manufacturing tasks within an application scenario from digitized industry. Further works also include investigations of new technologies as smart glass and tablets that can be applied to the design of the AIWS. Finally, testing has been scheduled to organise potential users working on the system. The entire process will be monitored for data analysis and further discussion. Together with feedback interviews of operators will be undertaken to derive and validate the criteria for industrial workplaces design, in terms of satisfying ergonomic requirements and reducing stress while interacting between the use and the system; and resulting to a high acceptance of the HRC.

A considerable relief of the worker's strain is to be expected by the use of the system. This will be validated within a future pilot experiment, in which the subjectively perceived workload is determined.

\section{References}

[1] Bannat A.: Ein Assistenzsystem zur digitalen Werker-Unterstützung in der industriellen Produktion. TU München, 2014.

[2] Bauernhansl T., ten Hompel M., Vogel-Heuser B. (Eds.): Industrie 4.0 in Produktion, Automatisierung und Logistik: Anwendung, Technologien, Migration. Springer Vieweg, Wiesbaden 2014.

[3] Braseth A. O.: Information-Rich Design: A Concept for Large-Screen Display Graphics: Design Principles and Graphic Elements for Real-World Complex Processes. Norwegian University of Science and Technology, 2015.

[4] Bullinger H.-J.: Ergonomie: Produkt- und Arbeitsplatzgestaltung. Vieweg+Teubner Verlag, Wiesbaden 1994. 
[5] Bullinger-Hoffmann A. C., Mühlstedt J.: Homo Sapiens Digitalis - Virtuelle Ergonomie und digitale Menschmodelle. Springer Vieweg, Wiesbaden 2016.

[6] Dostal W., Kamp A.-W., Lahner M., Seessle W. P.: Flexible Fertigungssysteme und Arbeitsplatzstrukturen. W. Kohlhammer GmbH, Stuttgart 1982.

[7] Endsley M. R., Jones D. G.: Designing for situation awareness: An approach to user-centered design. CRC Press, Boca Raton 2011

[8] Freitag M., Molzow-Voit F., Quandt M., Spöttl G.: Aktuelle Entwicklung der Robotik und ihre Implikationen für den Menschen. In: Molzow-Voit F., Quand M., Freitag M., Spöttl G. (Eds.): Robotik in der Logistik: Qualifizierung für Fachkräfte und Entscheider. Springer Gabler, Wiesbaden 2016, 9-20.

[9] Goschke T.: Aktivationstheoretische Ansätze: Motivation, Emotion, Volition. TU Dresden, 2013.

[10] Grendel H., Larek R., Riedel F., Wagner J. C.: Enabling manual assembly and integration of aerospace structures for Industry 4.0 - methods. New Production Technologies in Aerospace Industry: MIC Proceedings 2017, Hannover 2017.

[11] Hackl B., Wagner M., Attmer L., Baumann D.: New Work: Auf dem Weg zur neuen Arbeitswelt: Management-Impulse, Praxisbeispiele, Studien. Springer Gabler, Wiesbaden 2017.

[12] ten Hompel M., Henke M.: Logistik 4.0. in SpringerLink, Industrie 4.0 in Produktion, Automatisierung und Logistik. In: Bauernhansl T., ten Hompel M., Vogel-Heuser B. (Eds.): Anwendung, Technologien, Migration. Springer Vieweg, Wiesbaden 2014, 615-624

[13] Kunert G., Pawletta T.: Generating of Task-Based Controls for Joint-Arm Robots with Simulation-based Reinforcement Learning. SNE 28(4), 2018, 149 156.

[14] Kunert G., Pawletta T.: Generierung von Steuerungen für Gelenkarmroboter mit simulationsbasiertem Reinforcement-Learning. 24. Symposium Simulationstechnik ASIM 2018, 56, 2018.

[15] Larek R., Grendel H., Wagner J. C., Riedel F.: Industry 4.0 in manual assembly processes - a concept for real time production steering and decision making. Procedia CIRP 79, 2019, 165-169.

[16] Lee J. D., Wickens Ch. D., Liu Y., Boyle L. Ng: An introduction to human factors engineering: A beta version. CreateSpace Independent Publishing Platform, 2017.

[17] Lorenz M., Rüßmann M., Strack R., Lueth K. L., Bolle M.: Man and Machine in Industry 4.0: How Will Technology Transform the Industrial Workforce Through 2025? BCC The Boston Consulting Group, 2015.

[18] Michalos G. et al.: ROBO-PARTNER: Seamless Human-Robot Cooperation fo Intelligent, Flexible and Safe Operations in the Assembly Factories of the Future. Procedia CIRP 23, 2014, 71-76.

[19] Molzow-Voit F., Quandt M., Freitag M., Spöttl G. (Eds.): Robotik in der Logistik: Qualifizierung für Fachkräfte und Entscheider. Springer Gabler, Wiesbaden 2016.

[20] Norman D. A.: The design of everyday things. Basic Books, New York 2013.

[21] Onnasch L., Maier X., Jürgensohn T.: Mensch-Roboter-Interaktion - Eine Taxonomie für alle Anwendungsfälle. Bundesanstalt für Arbeitsschutz und Arbeitsmedizin 2016

[22] Sanders E. B.-N., Stappers P. J.: Co-creation and the new landscapes of design. CoDesign 4(1), 2008, 5-18.

[23] Spath D. et al. (Eds.): Produktionsarbeit der Zukunft - Industrie 4.0: Fraunhofe Verlag, 2013.

[24] Stark J., Mota R. R.C., Sharlin E.: Personal Space Intrusion in Human-Robot Collaboration. Companion of the 2018 ACM/IEEE International Conference on Human-Robot Interaction - HRI '18, 2018, 245-246.

[25] Vogel-Heuser B., Bauernhansl T., ten Hompel M.: Handbuch Industrie 4.0 Produktion. Springer-Verlag GmbH Deutschland, Berlin 2017.

[26] Wagner J. C., Larek R., Nüchter A.: Der Maximalnetzplan als Neuinterpretation der Netzplantechnik. Proc. of Wismarer Wirtschaftsinformatik-Tage 11, 2018, 123-136.

[27] Westkämper E., Spath D., Constantinescu C., Lentes J.: Digitale Produktion. Springer-Verlag Berlin Heidelberg, Berlin 2013

[28] Yerkes R. M., Dodson J. D.: The relation of strength of stimulus to rapidity of habit-formation. J. Comp. Neurol. Psychol. 18(5), 1908, 459-482.

[29] Ziegler J.: Wearables im industriellen Einsatz: Befähigung zu mobiler ITgestützter Arbeit durch verteilte tragbare Benutzungsschnittstellen. 2015.

[30] Acatech: Innovationspotenziale der Mensch-Maschine-Interaktion. Herbert Utz Verlag GmbH, Munich 2016.

[31] Acatech: Umsetzungsempfehlungen für das Zukunftsprojekt Industrie 4.0 Abschlussbericht des Arbeitskreises Industrie 4.0. Deutschlands Zukunft als Produktionsstandort sichern, Apr. 2013.

[32] AiF Projekt GmbH: ZIM-Erfolgsbeispiel: Exakt montiert - sicher verpackt zufriedene Kunden. Jan. 2018.

[33] Bundesministerium für Arbeit und Soziales Abteilung Grundsatzfragen des Sozialstaats, der Arbeitswelt und der sozialen Marktwirtschaft: WEISS BUCH Arbeiten 4.0: Arbeit weiter denken. 2017.

[34] Bundesministerium für Bildung und Forschung: Zukunft der Arbeit Innovationen für die Arbeit von morgen. 2016.

[35] Fraunhofer IAO: Arbeitswelten der Zukunft: Jahresbericht. FraunhoferGesellschaft 2017.

[36] International Ergonomics Association IEA, Definition and Domains of Ergonomics. https://www.iea.cc/ (Available: 25.02.2019).

[37] IXDS Human Industries Venture: Without design, Industry 4.0 will fail: Six challenges where design accelerates successful digital transformation in manufacturing. 2018, https://www.ixds.com/without-design-industry-40-willfail (Available: 27.06.2018)

[38] KUKA AG: Hello Industrie 4.0 - we go digital. https://www.nebbiolo.tech/wpcontent/uploads/KUKA-Industrie-4.0.pdf (Available: 19.06.2018)

[39] Steelcase Inc.: $360^{\circ}$ Focus Creativity: Creativity, Work and the Physical Environment. 17-0005439, 2017
Dipl.-Des. (FH) Johanna Ender

e-mail: johanna.ender@hs-wismar.de

Johanna Ender passed with distinction her graduation as Diplom Designer $(\mathrm{FH})$ for product design in 2017 at the Hochschule Wismar, University of Applied Sciences: Technology, Business and Design. She has started her international and interdisciplinary $\mathrm{Ph} . \mathrm{D}$. research in June 2017 at the Liverpool John Moores University - Faculty of Engineering and Technology. Awards: Gottlob-Frege-Price 2017, Anja-Schaible Price 2017, Innovation-Price 2018, German Design Award Nominee 2018, Science Slam Winner 2019 ORCID ID: 0000-0002-6827-3270

\section{Eng. Jan Cetric Wagner}

Cooperative Ph.D. student of Hochschule Wismar, University of Applied Sciences: Technology, Business and Design, and the Julius-Maximilians-University Würzburg. In 2016 he completed his master studies of mechanical engineering. He does research at the production engineering laboratory of the UAS Wismar in the research field of production organisation. His theory of the extended network plan helps to find alternative jobs in assembly tasks whereby downtimes can be reduced.

ORCID ID: 0000-0002-9236-2935

\section{Eng. Georg Kunert
e-mail: georg.kunert@hs-wismar.de}

Ph.D. student of Hochschule Wismar, University of Applied Sciences: Technology, Business and Design. In 2018 he completed his master studies of mechatronics. He is now researcher at the Research Group Computational Engineering \& Automation. His research interest machine learning algorithms and robot control that enables proactively interaction within humans and machines.

Awards: Gottlob-Frege-Price 2018, Science Slam Winner 2017

ORCID ID: 0000-0002-7469-8435

\section{Dr. Fang Bin Guo
e-mail: F.B.Guo@ljmu.ac.uk}

Dr. Fang Bin Guo has been a senior industrial designe with over 20 years' experience in product/spatial design. He is currently teaching BSc Product Design Engineering and supervising Ph.D. students' research in arts, design and creative technologies. Meanwhile, he remains actively involved in academic research His major researches incorporate identifications of contemporary role of design/designers, Human/user centred design; together with the studies of Human Factors and its application in new product development.

ORCID ID: 0000-0002-7442-7344
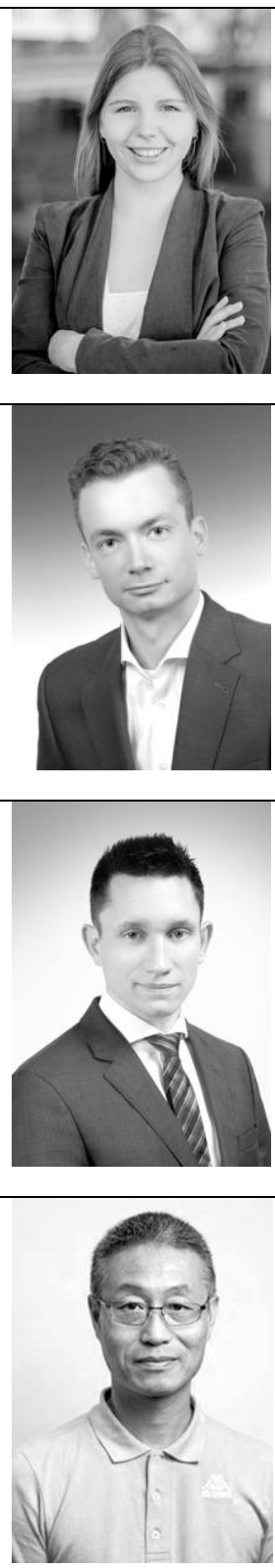

\section{Prof. Dr.- Ing. Roland Larek}

e-mail: roland.larek@hs-wismar.de

Prof. Dr.-Ing. Larek gained industrial experience among others at Airbus and a supplier to the wind power industry. Since 2013 he has been Professor for Production Engineering and Factory Planning at Hochschule Wismar, University of Applied Sciences: Technology, Business and Design. His research interest in the field of digital factory/Industry 4.0 has been documented in numerous publications.

ORCID ID: 0000-0003-2823-6237

\section{Prof. Dr.-Ing. Thorsten Pawletta}

e-mail: thorsten.pawletta@hs-wismar.de

Professor for Applied Computer Science at Hochschule Wismar, University of Applied Sciences: Technology, Business and Design, Germany. He is cofounder and member of the research group Computaional Engineering and Automation. His research incorporates modeling \& simulation theory and the application in engineering. He is member of the board of the German Simulation Society (ASIM) and member of the International Simulation Society (SCS).

ORCID ID: 0000-0003-1740-6560

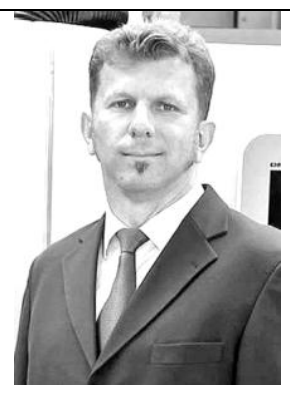

otrzymano/received: 08.08.2019 